\title{
Paradigma Nusantara Methodology Variety: Re-embedding Nusantara Values into Research Tools
}

\author{
Ari Kamayanti \\ Politeknik Negeri Malang, Jl. Soekarno Hatta no. 9, Malang 65144, East Java, Indonesia \\ ari.kamayanti@polinema.ac.id
}

\section{ARTICLE INFO}

Article history

Received 9 August 2021

Revised 15 August 2021

Accepted 20 August 2021

Keywords

Decolonization of science;

Nusantara methodology;

Paradigma Nusantara

\begin{abstract}
This article aims to offer an approach to derive Nusantara values into research methodology. Through substantive tenets (kaidah substantif) proposed by Mulawarman, methodology to construct variety of methods are put forward. There are three steps that must be taken to ensure that Paradigma Nusantara's tenets can become integral with research results, thus producing new or renewed Nusantara science. Paradigma Nusantara methodology will ensure that knowledge will be built upon strongly-believed values which cater creativity and freedom that will lead to decolonization of science. Examples of Paradigma Nusantara methodologies, both which have been executed and can be considered to be put to use are proposed in this article.
\end{abstract}

This is an open access article under the CC-BY-SA license

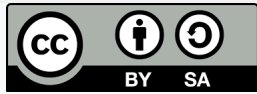

\section{Introduction}

Methodology is a study of why one method should be used to solve a research problem, and not another method. A researcher, for example, must be able to answer the question of why he uses multiple regression tests and not phenomenology in his research. The choice of methodology does not depend on the formulation of the problem or the researcher's preference for a particular method, but rather on the way the researcher sees the world. In the Western tradition this is known as lifeworld or lebenswelt [1]. If a researcher sees that the world is the result of a mechanistic, causal, and measurable phenomenon, he/she will formulate the problem mechanistic manner as well, such as what we have found numerously as the mainstream research question "does variable $\mathrm{x}$ affect variable y?"

In short, the methodology is the final consequence of a point of view. In the Western tradition, this is caused by a series of compatibility between ontology (belief in being or the existence of something), epistemology (belief in how to find knowledge or truth), methodology (assumptions or rules that limit the use of a method), and finally axiology (the purpose of knowledge) [2,3]. The following outcome is a research method that comprises step-by-step techniques by which researchers collect data, analyze, and present it. 
I have deliberately restated the term "Western tradition", because the trilogy of ontology-epistemology-axiology has sprung from this tradition, which is the result of the underlying assumptions about social reality, science, humans, nature, and the usefulness of science [4-6]. If you are observant enough, you will see that there is no "God" in this paradoxical set of assumptions. This is not accidental. The modern paradigm is driven by a massive secularism movement that separates religious values from science [7].

We need to understand the various paradigms in the social sciences to be able to compare them with Paradigma Nusantara. Burrell \& Morgan's (1979) modern classification of paradigms is one of the most phenomenal and has become a kind of "holy book" for non-positivism adherents. In their book, "Social Paradigms and Organizational Analysis: Elements of the Sociology of Corporate Life", they classify 4 (four) paradigms: Functionalism/Positivism, Interpretivism, Radical Humanism, Radical Structuralism. This division is arranged by mapping them in 4 (four) quadrants with vertical lines (which are assumptions about the orderliness of society at the lowest continuum, and radical changes at the top continuum) and the horizontal line (which is a continuum about belief in science, from the far right that science must be objective, and to the far left science is the creation of subjectivity). Others classify the modern paradigm differently [5,6,8], yet one character remains the same: separation from God and cultural values.

The modern paradigm (or commonly referred to as the Western paradigm) was born out of public disillusionment with the church's authority to confirm the validity of science. Galileo was accused of heresy since he revealed that it was the sun that is the center of the planets, not the earth. His revelation was considered a resistance to the Catholic church's authority over science. The spirit of "enlightenment" was born, the rebirth of the "renaissance" of science without having to involve God. In 1633 he was sentenced:

"We pronounce, judge, and declare, that you, the said Galileo... have rendered yourself vehemently suspected by this Holy Office of heresy, that is, of having believed and held the doctrine (which is false and contrary to the Holy and Divine Scriptures)...We order that by a public edict the book of Dialogues of Galileo Galilei be prohibited, and We condemn thee to the prison of this Holy Office during Our will and pleasure; and as a salutary penance We enjoin on thee that for the space of three years thou shalt recite once a week the Seven Penitential Psalms." [9]

The secularism pervades from the West to the East, including to the South Asian archipelago, formerly known as the Nusantara. It is naïve to say that knowledge is valuefree, since every knowledge is embedded with interest derived from underlying values. Thus, when "Western-Secular" science is diffused to Nusantara, a process understood as the spreading of values from superior to inferior culture, it is not just the knowledge that changes. The people practicing the knowledge will also evolve to become one with the secular values.

Modern paradigm, hence, poses real and true danger to the keeping of Nusantara identity and way of life, which has intertwining religious and cultural values. Mulawarman has urged the necessity of redirecting science to Nusantara roots by employing Paradigma Nusantara [10] as a lifeworld for Nusantara people. There is no assumption an integral 
perspective between God and social reality. It is a certainty, hence it is a tenet or kaidah. The social reality in the Paradigma Nusantara is a reality that is full of local values with the breath of religiosity that is present contextually in a certain space and time. Changes in social reality in the present or in the future will not be able to erase the traces of the original values that are inherent or embedded in cultural objects and people. The nature of context will definitely distinguish how cultural practices are attached to a particular place, but the tenet of religiosity will not fade.

It is interesting to observe how the Paradigma Nusantara has actually been embodied in Islamic (Accounting) Anthropology [11,12] which answered the challenge of Ahmed (1989) to use Islamic anthropology. In mapping civilization, we have created a scheme about cultural diffusion and dreams to reach the Islamic epicenter, where all forms of wisdom and locality values that have been purified become a major civilization or Islamic Epicentrum Society. God's holy verse that asks people to know each other becomes a real praxis, filled with the spirit of peace and mutual respect, so that the best society (khoiru ummah) emerges.

Specifically this paper will explain how various methodologies of the Nusantara Paradigm were formed, as well as concrete examples of their use in research. The paper further proposes how Paradigma Nusantara and its derived methodologies will liberate researchers and construct reality according to the basic values believed.

\section{Method}

Deriving Nusantara methodology from Paradigma Nusantara is done by first placing the four kaidah/tenets as the basis. The four tenets are: Nusantara being, integral view of reality, religiousity and culture, and the objective of Nusantara knowledge [10]. These four tenets must be elaborated in terms of their connectivity to each other. Next, I will use three steps to design Nusantara methodology. The three steps are (1) determining contextual Nusantara values either from culture or prominent figures' thoughts that will be used as basis of methodology, (2) understanding and identifying Nusantara contextual values that will be derived as methodology, and (3) reconstructing reality based on the values.

Various Nusantara methodologies that have been created and devised are then elaborated in terms of the three steps and the adherence to the four tenets. My own reflections which are parts of empirical evidence of Paradigma Nusantara are also elucidated.

\section{Results and Discussions}

\subsection{Identifying connectivity of the four tenets}

It should be understood that the four tenets are not chronologically or hierarchically ordered. The four tenets are intertwined and this section will highlight their connectivity. The first tenet is Nusantara being.

Nusantara being can be defined as individual and its collectivity (ummah) in the Nusantara archipelago who are conscious of the existence of Nusantara as one of the highest civilization in the word, since every individual and its collectivity believe that they 
are the messengers of God, servants of God, and the universe caretaker. When everyone believes he/she is the messenger of God, not to say prophet, but one who is obliged to preach God's teachings and practice them, then every thought, saying, and action will never deviate from God's will. This will include the knowledge building activities.

Nusantara is indeed one of the highest civilization because of its strong spiritual character that will not pursue only materials achievement. Ahmad, Rahman and Nuraripah concur this idea as "Nusantara Spiritual Civilization":

"The construction of a spiritual civilization developed through the interpretation of the prophetic mission is in line and can take a role in maximizing the potential of the nation's spirituality treasures. This can happen to the potential of the archipelago, which in general has a strong attachment to God or something unseen. The construction of a spiritual civilization that has been built provides a fundamental solution in developing that potential where tazkiya (self-purification) is a condition for achieving the perfection of each human in a society". [13]

The second tenet is integral view of reality. It means that reality is an integral unity between material-spiritual elements that exist in the past, present, and future that intertwine until the end of time (eschatological world) in which at all of these points of time God is always present. This tenet will bear logical consequence on knowledge building. If one holds on to this tenet, then one will not be trapped into either rationalism or empiricism. One will also acknowledge that knowledge is both material and spiritual that must be used at all times to achieve the ultimate welfare in the afterlife. Such reality will not deviate man in producing knowledge that will cause injustice or marginalization for people (ummah). In business practice, for example, one will never even consider, let alone practice interest ( $r i b a$ ) since it is forbidden, bears sanctions in afterlife and would cause injustice in the world. It takes a true Nusantara being to realize that reality is never separated from God [14].

The third tenet is religiosity and culture. This tenet will cause one to believe that religions, being God's guidance in the world and afterlife, would permeate into all aspects of life. Human beings are social beings hence they will form social interactions governed by norms. Religions undoubtedly will be one norm that is surely embedded in the Nusantara being in the form of culture. Hence, the Nusantara people will always posses religious culture. For example, in Javanese culture, slametan is a ritual for thanksgiving to God. This cultural ritual is introduced by the preacher, known as Wali Songo. In slametan religious aspects are deeply embedded [15] even in noting down social debts. Another example is wayang, a traditional puppet show [16] that tell the epic story such as Mahabarata or Ramayana that also bears religious teachings.

The fourth tenet is the objective of science that is based on true faith and absolute truth. This tenet implies that science must always be employed to reconstruct realities as ordered by the Divine Will, according to Nusantara's religiosity and culture, which will enable every one in Nusantara to keep hes/her Nusantara being. If this tenet is upheld, then we will not witness colonialism in the name of better civilization.

These four tenets are intertwined. They do not exist in hierarchical order nor possess dominance over others. Every tenet must be adhered to in Paradigma Nusantara. There 
should be no exception. If one tenet is kept, then the other three will also be simultaneously followed. For example a Nusantara being who believes he/she is a servant of God and believes in God (Tenet Number 1) would of course see that all knowledge must be purposed to create reality as God would wish it (Tenet Number 4). As a result, his/her understanding that God exists in reality would enable him/her to see that culture and religions are intertwined (Tenet Number 3) and that this reality in an integral view of material-spiritual elements (Tenet Number 2). Either way placed, all tenets will always support one another.

\subsection{Three steps in designing Nusantara methodology}

There are three steps that one must follow in designing Nusantara methodology. These steps can only be derived when all four kaidah or tenets have been upheld. These three steps will cater a reseacher's freedom to devise any Nusantara methodology without leaving the four tenets.

\subsubsection{Recognizing contextual values in Nusantara}

Indonesian proverb "Di mana tanah dipijak, di situ langit dijunjung" (translation: where ground is stepped upon, values must be upheld) could be the first guidance in choosing the Nusantara Methodology to be used. A researcher who adheres to the Paradigma Nusantara must understand that cultural differences exist, and that each region has its own culture. Next, he/she must understand that culture does not emerge as a mere practice, but because of societal norms, which are further embedded in the root of values. As an adherent of the Paradigma Nusantara, he/she must also believe that the values of each culture cannot be separated from the roots of his belief in the existence of God.

By understanding that each region has different values, then in the spirit of mutual respect, if he/she wants to construct reality according to the values he/she believes in, then he/she needs to believe that these values are true and cannot be replaced by other cultural values. In this case, the construction of reality will certainly be the main goal of the Paradigma Nusantara because of the rapid globalization and industrialization which is increasingly distancing the current reality from the reality of the value of local wisdom.

For example, a researcher who wants to construct a taxation reality in Bali using the Tri Hita Karana value, where the value consists of Parahyangan (worship of God), Pawongan (respect for humans), and palemahan (respect for the earth/environment) must believe that Bali cannot but use these values as the basis for the construction of reality. If the researcher comes from Java, for example, he/she believes in adigang, adigung, adiguna (do not boast to be powerful, do not be pretentious, do not feel you can do everything), then he/she cannot use these values- even though they are true - to construct reality in Bali.

In the end, the more we understand cultural diversity and interconnection between regions (eg the relationship between Java and Bali related to the spread of Majapahit to Bali), of course, this interconnectivity has created a strong wedge between cultures. Tasyakuran culture is almost everywhere in Java, although with slightly different variants. Regardless of the similarities that may arise, it is important for a researcher who adheres to the Paradigma Nusantara to believe in the importance of local values which are the basis for the construction of the regional reality. 


\subsubsection{Identifying Nusantara values that will be used as methodology basis}

After a researcher understands the basic values of the area from which his reality will be constructed, next he/she needs to choose which values he will adopt as the basis of construction. It is called "values" because it is impossible for an area to have only one value.

However, taken more broadly, the Nusantara implies a collection of cultures itself, as expressed in the slogan Bhinneka Tunggal Ika (Different but in One) in Indonesia. The term Nusantara itself is actually not limited to one Indonesia. The term Nusantara is a state term used by Majapahit in the 12th to 16th centuries. The Nusantara covers Southeast Asia, including most of Indonesia, and the Malay Peninsula (Malay Archipelago).

By taking into account the scope of this area, Paradigma Nusantara methodology does not have to be tied to one culture only but also to a nation/state/nation. This is very important to keep in mind because the choice of methodology can be tied to the thoughts of nationalists or state heroes who are fighting to liberate the nation, not just to liberate one region.

\subsubsection{Reconstructing Nusantara realities}

Final step is the use of the values as reality construction. In Nusantara methodology, one must not simply see values as some things that are revealed and explored to achieve a deeper understanding or verstehen, as in interpretive tradition. Values must be basis of reality construction, not findings.

Hence, a researcher must first deal with the reality he/she faces then analyse the values underlying the existing reality. He/she then must investigate why the existing reality does not follow the four tenets of Paradigma Nusantara, which implies the searching of values that are defiant from Nusantara values. He/she must then use the chosen/determined Nusantara values to redirect reality accordingly.

\subsection{Variety of Nusantara methodologies and methods}

The three steps will help researcher to devise Nusantara methodology, and as a consequence methods, to reconstruct Nusantara reality, in the most flexible ways possible according to the chosen Nusantara values believed and upheld. These values still exist in everyday life of Nusantara people. As an empirical finding, a meeting in August 2021, on the building of mosque and free education centre in Nusa Tenggara Barat, Indonesia, revealed that the practice of tree harvesting must adhere to traditions to respect nature. One prominent figure, a head of Indonesian Muslims Ulama/ Scholars (MUI) Sumbawa explained that in order to harvest trees that will be used for building materials, traditions are still kept:

"Tradisi menebang kayu di Sumbawa sangat penting. Ada ritual penghormatan untuk pohon yang akan ditebang agar tidak dimakan rayap maupun lapuk. Tradisi ini masih dijaga."

He explained that respect for nature is a culture held even in tree harvesting. This culture is closely tied in the teaching of religions that one should keep and respect nature, not exploit it. By keeping this tradition, the nature will reward human with good quality 
tree that will not be easily eaten by termites. Such values must not only be understood but must be used as basis for reality construction.

I once wrote about the use of Tjoet Njak Dhien's fight as accounting research methodology [17]. The research methodology construction is not based on the chronological order of the fight itself, but on the values behind the heroine's fight. It was the keeping of tauhid (belief in one God), the values of obedience, the love of a mother by Tjoet Njak Dhien that are used as values to construct realities.

The values of Tjoet Njak Dhien's fight are then derived into three-steps method. First, exploring literary sources, gathering documents, and interviews on the phenomenon being studied. Second, giving empirical evidence on how practices have deviated from the religious values by analyzing them with the holy book. Third, through Hikayat Perang Sabil (in Aceh, this is songs/poems that are sung/read to ignite the fighting spirit during war), a metaphor must be used to raise consciousness that realities must be reconstructed. Fourth, proposing regulations that may support the change of practice. Fifth, ensuring that there is no room for compromise in terms of idealism/upholding values.

Mulawarman employed Nataatmadja's thought as methodology [18]. He refused to bet trapped into modern philosophical assumptions, but instead he abstracted kaidah that in his paper he termed as "rukun".

"Rukun Sentral Keilmuan Semesta ala Hidayat Nataatmadja menganut tiga rukun turunan. Pertama, Rukun Paritas, merupakan manifestasi dari ayat yang menyatakan bahwa Allah menciptakan segala sesuatu dalam pasangan-pasangan, yang berarti objektifitas itu harus subyektif (Nataatmadja 1994:37). Kedua, Rukun Kewargaan, bersama-sama dengan Rukun Paritas membentuk paradigma keilmuan baru dengan Rukun Iman sebagai intinya, yang menolak pendekatan individualistik dan atomistik, tetapi lebih mengutamakan kebersamaan, dan kesatuan segala sesuatu (Nataatmadja 1994:43). ” [18]

Rukun Sentral Keilmuan or the tenet of central of science results in three derivations. First, parity tenet; second, societal tenet, which together with parity tenet will form new science with faith tenet as its core. This approach will deny individualistic or atomistic approach, but will prioritize togetherness and unity of everything. This Nataatmadja methodology is a Paradigma Nusantara methodology since all four tenets of Paradigma Nusantara have been followed, while all the three steps have been extended to suit its need.

Another reconstructive methodology for accounting that employs Nusantara methodology, though not explicitly stated is the use if Bantengan and Topeng Malang. Bantengan and Topeng Malang are traditional show that are dense with fighting spirits. The reseachers stated:

Pada tahap selanjutnya, "organ persepsi” berbentuk karakter serta nilai kesenian Topeng dan Bantengan digunakan untuk menjelaskan kondisi perang kuasa akuntansi pada level supranasional (ningrat) dan pada level lokal (rakyat jelata). Bahasa persuasif digunakan untuk memberikan penyadaran pentingnya keberadaan perang level lokal yang akan menghasilkan akuntansi yang lebih konkrit bagi kepentingan rakyat." [19] 
The traditional arts that were invented during the war against the colonialism in Indonesia are claimed relevants to today's realities especially in accounting science and practice. The ningrat or the royal refers to the few elites who possess powers and must be made aware that accounting practices that are now oriented for stock holders are marginalizing the lokal rakyat jelata or the common people. The values employed in the paper are from the traditional arts, and again, the authors refused to be trapped in the modern philosophy of science. The purpose of the article is also to reconstruct accounting for the welfare of the people. Godliness value is also raised in the paper:

"Kesenian Bantengan mengingatkan manusia untuk selalu menjaga hubungan terhadap Tuhan, sesama manusia serta bangsa-bangsa yang ada di alam ini, tanpa ada rasa kesombongan karena merasa menjadi makhluk ciptaan Tuhan yang pa- ling sempurna. Banteng dalam kesenian Bantengan ini melawan hawa nafsu, rasa iri dengki serta hal-hal yang buruk yang dilambangkan sebagai macan, monyet dan abang- abang...". [19]

One must not confuse methodologies and methods. Methodologies imply kaidah that must be adhered to, a reason why one must use specific methodology, not other alternatives. Methods, on the other hands are specific techniques- a step by step guidance to solve problems.

For example, one may choose to use the thoughts of HOS Tjokroaminoto or Nataatmadja, such as once conducted by Mulawarman [20,21], but when it come to method, one can still use literary study or documentation as data collection method. One can also still use interviews or observations as collection method as well. However, it is the methodology that ensures the adherence to the four tenets.

\section{Conclusion}

The article has proposed steps to design Nusantara methodology that will help researcher keep the four tenets of Paradigma Nusantara, which are Nusantara being, integral view of reality, religiosity and culture, and objective of science based on true belief and absolute truth. The three steps are recognizing contextual values in Nusantara, identifying Nusantara values that will be used as methodology basis, and reconstructing Nusantara realities.

The four tenets are intertwined, non-hierarchical and must be followed when applying the three steps. The results are the creation of unlimited Nusantara methodologies that will enable decolonization of science. Contextualities of Nusantara values enable the researcher to use his/her creativities to devise Nusantara methodologies.

By employing various Nusantara methodologies, Nusantara realities can be reconstructed through decolonized science that can be put into practices. This is to say, that we will hope to see the emergence of renewed science suited to its contextualities.

\section{References:}

[1] Ritzer G. The Blackwell Companion to Major Social Theorists. USA: Blackwell Publishing; 2000.

[2] Kamayanti A. Metodologi Penelitian Kualitatif Akuntansi: Pengantar Religiositas 
Keilmuan. Jakarta: Rumah Peneleh; 2016.

[3] Kamayanti A. Metodologi Konstruktif Riset Akuntansi: Membumikan Religiositas. Jakarta: Yayasan Rumah Peneleh; 2017.

[4] Burrell G, Morgan G. Sociological Paradigms and Organisational Analysis: Elements of the Sociology of Corporate Life. Great Britain: Arena; 1979.

[5] Chua WF. Radical Developments in Accounting Thought. Account Rev 1986;61:601-32.

[6] Sarantakos S. Social Research. Melbourne: Macmilan Education Australia; 1993.

[7] Al Attas SMN. Islam dan Sekularisme. Bandung: Penerbit Pustaka; 1981.

[8] Kaidonis M, Moerman L, Rudkin K. Paradigm, paradox, paralysis: An epistemic process. Account Forum 2009;33:285-9. doi:10.1016/j.accfor.2009.10.001.

[9] Editors H co. Galileo is accused of heresy n.d. https://www.history.com/this-day-inhistory/galileo-is-accused-of-heresy (accessed August 14, 2021).

[10] Mulawarman. AD. Paradigma Nusantara: Decolonizing (Accounting) Science Agenda. Int J Relig Cult Sci 2021;3:99-124.

[11] Mulawarman AD, Kamayanti A. Islamic accounting anthropology: a constructivist methodological alternative. Int J Bus Soc 2018;19:302-11.

[12] Mulawarman AD, Kamayanti A. Towards Islamic Accounting Anthropology: How secular anthropology reshaped accounting in Indonesia. J Islam Account Bus Res 2018;9:629-47. doi:10.1108/JIABR-02-2015-0004.

[13] Achmad A, Rahman F, Nuraripah P. Țabațaba'i Interpretation on Prophetic Mission in Tafsir Al-Mizan for the Construction of Nusantara Spiritual Civilization. Teosofia 2020;9:91. doi:10.21580/tos.v9i1.5328.

[14] Kamayanti A. Fobi(a)kuntansi: Puisisasi dan Refleksi Hakikat. J Akunt Multiparadigma 2016;7:1-16. doi:http://dx.doi.org/10.18202/jamal.2016.04.7001.

[15] Kamayanti A, Ahmar N. Tracing Accounting in Javanese Tradition. Int J Relig Cult Stud 2019;1:15-24. doi:10.34199/ijracs.2019.4.003.

[16] Koesoemadinata MIP. Wayang Kulit Cirebon: Warisan Diplomasi Seni Budaya Nusantara. ITB J Vis Art Des 2013;4:142-54. doi:10.5614/itbj.vad.2013.4.2.6.

[17] Kamayanti A. Riset Akuntansi Kritis: Pendekatan (Non) Feminisme Tjoet Njak Dhien. J Akunt Multiparadigma 2013;4:361-75.

[18] Mulawarman AD. Nyanyian Metodologi Akuntansi ala Nataatmadja: Melampaui Derridian Mengembangkan Pemikiran Bangsa "Sendiri." J Akunt Multiparadigma 2013;4. doi:10.18202/jamal.2013.04.7189.

[19] Kusdewanti AI, Madura) ARS (Universitas T, Mulawarman. AD. Akuntansi Bantengan: Perlawanan Akuntansi Indonesia Melalui Metafora Bantengan Dan Topeng Malang. J Akunt Multiparadigma 2014;5:149-69.

[20] Mulawarman. AD. Akuntansi "Tjokro-an" Kritis ala HOS Tjokroaminoto. Ekon J Paradig Islam Di Bid Ekon Keuangan, Dan Pembang 2014;2:24-37.

[21] Mulawarman AD. Nyanyian metodelogi akuntansi ala nataatmaja: melampaui derridian mengembangkan pemikiran bangsa sendiri. J Akunt Multiparadigma 2013;4 (1):149-64. 
This page is left intentionally blank 